\title{
Competition Pressures and Academic Performance in Chile*
} Presiones competitivas y desempeño académico en Chile

\author{
Rómulo A. Chumacero** \\ JuAn Gallegos MaRdones*** \\ RICARDO D. PAREDES $* * * *$
}

\begin{abstract}
The positive impact that competition has on performance in most industries has been questioned in the education sector. The difficulty to measure competition, the idea that parents don't rationally choose schools for their children, and that schools do not react to that choice is in the center of the debate. We critically analyze the prevailing methodology in the literature that relates competition and educational performance, and the data used to estimate that impact. We propose a methodology that considers relevant substitutes for each school using various attributes which parents consider when choosing schools, and we apply it to estimate the effect of competition on educational performance in Chile, were more than $90 \%$ of the students are covered by a voucher. The evidence supports the hypothesis that competition has a positive, statistically significant, and economically relevant educational impact on private and public schools.
\end{abstract}

Key words: Vouchers, competition, performance.

JEL Classification: $I 21, L 1$.

\section{Resumen}

El efecto positivo que la competencia suele tener en el desempeño en la mayoría de las industrias ha sido cuestionado en el sector educativo. La dificultad en medir competencia y la idea que los padres pueden no ser racionales al momento de elegir escuelas para sus hijos, además que las escuelas no respondan a estas

* Comments by C. Vial, S. Maturana, O. Melo, D. Gómez, and two anonymous referees are gratefully acknowledged. Special thanks to MINEDUC for granting Access to its data base. Financial support from Fondecyt (Project 1140980) and CEPPE (project CIE01-Conicyt) are acknowledged. The usual disclaimer applies.

** Department of Economics, Universidad de Chile, rchumace@econ.uchile.cl.

*** Escuela de Ingeniería, Pontificia Universidad Católica de Chile and Facultad de Ciencias Económicas y Administrativas, Universidad Católica de la Santísima Concepción, jagalleg@uc.cl.

**** Escuela de Ingeniería, Pontificia Universidad Católica de Chile and Duoc UC, rparedes@ ing.puc.cl. 
elecciones, son componentes esenciales del debate. Se realiza una evaluación crítica de la metodología prevalente para medir la relación entre competencia y desempeño. Se propone una metodología que considera a sustitutos relevantes de cada escuela, tomando en cuenta los atributos utilizados por los padres en la elección de escuela. La evidencia favorece la hipótesis que la competencia tiene un efecto positivo, significativo y económicamente relevante en el desempeño de las escuelas.

Palabras clave: Vouchers, competencia, desempeño.

Clasificación JEL: I21, L1.

\section{INTRODUCTION}

In the 1980s, Chile transformed its educational system, which was experiencing low academic performance and high dropout rates. This reform introduced mass decentralization, placing schools under the management of municipalities, and allowed private schools to receive a subsidy through vouchers, which were also introduced to finance public schools. A change in the law in 1992 allowed parents to complement the voucher provided by the Government generated a massive influx of new schools, which, unequivocally changed the competitive landscape and has driven a significant reduction in public education to favor private subsidized schools (see Paredes and Pinto, 2009). By 2013, the Chilean school voucher covered $93 \%$ of student enrollment, making it the broadest reaching voucher system in the World. ${ }^{1}$

The effect a voucher system has on academic performance is a highly controversial topic. The capacity of a voucher system to improve learning depends on the ability parents have to choose schools based on quality and on the capacity schools have to respond on the incentives competition creates (see Chumacero and Paredes, 2012a). To analyze competition, most studies associate competition to the number of private schools in a given geographic area, where the areas are defined following administrative or geographical criteria (i.e., counties). This proxy for competition is misleading when, as in the Chilean case, students have the freedom to choose their school, independently of the neighborhood where they live.

Furthermore, estimating the impact competition has on academic results using cross-sectional data is also misleading. This method follows classic industrial organizational research on the relationship between competition and performance (e.g., Bain, 1956; Demsetz, 1973; Keppler, 2008; and Rosado, 2008). Cross sectional analysis is correct when, for instance, barriers to entry differ across industries in a given moment, and hence there is variance in competition across industries. However, this methodology is incorrect when competition does not differ in a given moment, as for instance, when the same potential entry is present in different "sub markets." If this were the case, firms would decide

1 In the past couple of years, several reforms to the voucher system have been proposed and implemented. 
entry in the sub markets with higher potential profits, and hence, returns would be equal among them.

The change in the competitive environment that affected schools in Chile was not the same for each school. In this paper we propose a proxy to correctly measure the effect in competitive pressures affecting different schools and we evaluate that effect on academic performance. The rest of the paper is organized as follows: Section 2 presents an overview of the educational system in Chile, as well as a review of relevant literature. Section 3 describes the methodology and the results. Finally, section 4 concludes.

\section{BACKGROUND}

\subsection{The Chilean Educational System}

Until the early 1980 s, nearly $80 \%$ of the country's schools were run by the State. The Ministry of Education was in charge of funding and running Chile's schools, supervising and developing curricula, and investing in and building public school infrastructure. The system had high dropout and repetition rates, and was viewed as delivering a poor-quality education owing to its excessively bureaucratic nature, insufficient coverage and failure to provide schools with proper incentives. ${ }^{2}$ This motivated a far-ranging reform of the education system based on a voucher system (Friedman, 1962). Chile was one of the first countries in the World to introduce a reform of this type, or at least a reform of this scale and nature. State-run schools were handed over to the municipalities and were financed with subsidies that did not differentiate between students attending municipal schools and those attending non-fee private voucher schools (Mizala and Romaguera 1998). This reform was in the line of several structural reforms in Chile in the late 1970s, including market and choice elements (Castañeda, 1991; Cox, 2003). Thus, the reform gave rise to three types of schools: (i) municipal, State-funded schools (with funding provided by per-student subsidies); ii) privately run, State-funded subsidized schools (with funding provided by per-student subsidies); and (iii) privately run schools funded by tuition payments.

Since the early 1980s, the system has gone through numerous modifications, in response to an analysis to improve quality levels and equality (Cox and Lemaitre, 1999). One of such changes was the Program for Educational Quality and Equality (MECE), which incorporated a systematic intervention of processes and conditions used in education, with an emphasis on the segment of students and schools that were falling furthest behind. In 1995 the results for the standardized SIMCE tests were published for each institution. This standardized test measures the achievement of educational objectives and is taken by all students in 4th grade and 8th grade, with the exception of students who studied

2 Hanushek (2003) suggests, for example, that in 1970 the test scores for Chile's students were $50 \%$ lower than the those of students in France and the United States, $20 \%$ lower than those of students in Japan and were only $10 \%$ higher than students in India and the Islamic Republic of Iran. Barro (1999) reported that Chile's scores were 50\% lower than what they would be expected to be, given its level of development. 
in multi-grade classrooms. Tests for 10th graders were incorporated in 1998. The publication of these results was done so parents would have information regarding schools' performance, a key element in making proper decisions.

In 1993 a provision was introduced to supplement State funding. Under this statute, some of the subsidized schools were allowed to charge parents for a portion of the tuition, and subsidized private schools and some public schools were authorized to receive donations or grants, which would be deducted from the State subsidy. This led to a steep rise in private school enrolment that has cast some doubt over the sustainability of the municipal school system (Table 1). These policies succeeded in bringing about a steep reduction in dropout rates and a steady increase in enrolment rates. The scores on the System for Measuring the Quality of Education (SIMCE) tests, however, indicate that the quality of education remains quite limited and that striking differences between the performances of students in different socio-economic sectors continue to pose a major challenge. ${ }^{3}$

TABLE 1

NUMBER OF SCHOOLS BY TYPE

\begin{tabular}{|ccccc|}
\hline Year & Total & Municipal & Private Subsidized & Private Paid \\
\hline 1990 & 9,811 & 6,359 & 2,694 & 758 \\
1991 & 9,801 & 6,346 & 2,678 & 777 \\
1992 & 9,802 & 6,364 & 2,651 & 787 \\
1993 & 9,831 & 6,347 & 2,653 & 831 \\
1994 & 9,810 & 6,313 & 2,637 & 860 \\
1995 & 10,296 & 6,448 & 2,790 & 1,058 \\
1996 & 10,515 & 6,527 & 2,883 & 1,105 \\
1997 & 10,318 & 6,411 & 2,857 & 1,050 \\
1998 & 10,631 & 6,407 & 3,065 & 1,159 \\
1999 & 10,712 & 6,367 & 3,170 & 1,175 \\
2000 & 10,610 & 6,325 & 3,217 & 1,068 \\
2001 & 10,799 & 6,309 & 3,459 & 1,031 \\
2002 & 10,879 & 6,248 & 3,640 & 991 \\
2003 & 11,223 & 6,209 & 4,084 & 930 \\
2004 & 11,296 & 6,160 & 4,274 & 862 \\
2005 & 11,561 & 6,168 & 4,630 & 763 \\
2006 & 11,671 & 6,041 & 4,897 & 733 \\
2007 & 11,763 & 5,979 & 5,054 & 730 \\
2008 & 11,905 & 5,917 & 5,262 & 726 \\
2009 & 12,116 & 5,899 & 5,536 & 681 \\
\hline
\end{tabular}

Source: MINEDUC.

The conceptual and empirical foundations underlying this discussion about the consequences of the reform clearly extend beyond the specific case of Chile. Hanushek (2003) suggests that the cost of public education has risen sharply

3 Chilean students scored substantially higher on PISA 2006, especially in language. 
without attaining the expected results. Chubb (2001) contends that, if education were privatized, schools would have powerful incentives for cutting costs and that this would push them to innovate and become more efficient. Others argue that this type of system would prompt private schools to cut costs in ways (e.g., recruiting less qualified teachers at lower salaries) that would lower the quality of the education that they provide. In addition, this system could lead to discriminatory practices whereby schools would give preference to students that would be less costly for them (Levin, 2002). In Hoxby's view (2000), this kind of situation arises because, in a flat-rate subsidization system, subsidized private schools have no incentive to take on students who are in more vulnerable situations, since they will require a larger investment in order to achieve better scores.

Regarding the consequences of the Chilean reforms, there is a consensus that the reform increased coverage and reduced repetition rates. However, most analysts also find low quality of education, and that the results and the intellectual ability are strongly stratified and that the level of education is unsatisfactory by international standards (see, Heyneman, 1990 and 2004; Brunner, 2005; García and Paredes, 2010).

Besides learning, the literature states a main concern regarding segregation. Hsieh and Urquiola (2003) argue that the reform spurred an exodus of middleclass students from municipal schools to private subsidized ones, which left the municipal schools with a much greater proportion of students from vulnerable sectors and therefore drove down their average scores. Tokman (2004) and Valenzuela et al. (2008) suggest that allowing parents to pay in a State voucher context explains Chile's high segregation shown in the PISA2006 report. Using Simce scores, the same concern is present in Mizala and Torche (2012). More recently, Paredes et al. (2013) decomposing segregation within and between schools, suggest that most segregation observed is between school types, and it is particularly high in the private paid schools.

\subsection{Competition and Performance}

The introduction of competition through a voucher system could induce schools to improve performance (Hoxby, 2001). Competition among schools is expected to increase social welfare when families can choose and school budgets depend on family decisions. Pioneering research on the relationship between competition and academic performance was done by Borland and Howsen (1992) as well as Couch et al. (1993). Using cross section, Borland and Howsen (1992) measured the level of competition by the relative participation of private schools in the State of Kentucky, finding a positive relationship between this and academic performance. Likewise, Couch et al. (1993) measured competition as the percentage of students who attend private schools and they found a positive and significant relationship between the competition provided by these private schools and academic performance of public schools in 100 counties in the State of North Carolina.

Hoxby $(1994,2000)$ used a Tiebout (1956) type of model with cross-sectional data, which included choices based on the proximity between school and the family residence. The model assumed that public schools have access to parental information regarding resource productivity. So, including private schools (which are assumed to operate with greater productivity) provided information regard- 
ing academic productivity, and limited the agency problem. Results suggest that the greater the competition provided by private schools, the greater the efficiency of public schools, raising performance levels, teacher salaries and high school graduation rates.

Epple and Romano (1998) develop a theoretical computational model with public schools financed by taxes, private schools financed with a voucher system, and students with varying abilities and incomes. Their results showed that the performance of these schools are explained by the students' socioeconomic factors; they also demonstrated that the voucher system drives private sector growth and sorting, which benefits the most qualified students as compared to those with lower grades. Romano and Epple (2002) studied a voucher system designed to increase competition, without creating student sorting. To achieve this, they corrected their prior model, varying the voucher based on students' abilities. The results of this model indicated that a voucher system that recognizes student characteristics can reach higher levels of efficiency, increasing quality of results and equality in private and public schools.

Toma (1996) evaluated the effect of private school enrollment and the financing system in five countries. She finds that the public effort to promote private enrollment does not reduce the public school performance and that the government restrictions on decision making reduced the private school performance. Sander (1999), also using a cross-sectional analysis evaluated how competition by private schools affect mathematical performance in public primary and secondary education in Illinois. The proxy for competition used is the percentage of students enrolled in private schools, dealt with the endogeneity of this variable by using the density of the Catholic population per neighborhood as an instrument, and conclude that competition provided by private schools has no direct effect on the performance of public schools.

Ladd and Fiske (2001) evaluated the effects of the 1991 reform which provided complete freedom of school choice and created competitive conditions between primary schools in New Zealand in 1996. They concluded that greater competition, measured as the percentage of private schools, negatively affected students' learning, learning styles, relationships with parents and relationships with the principals.

Bayer and McMillan (2005) also focused on the impact of free choice on public school performance using information from the 1990 Census for the San Francisco Bay area. They developed a more direct measure of competition faced by each of the schools, associated with the effect of a reduction in quality in the school demand. The authors use as an instrument the price of homes in the area where the schools were located. The results showed that competition is closely and positively related to academic performance of the schools.

Braun-Munzinger (2005) conducted a review of 21 voucher programs in 14 countries and identified factors which impact the quality of education through competition between schools. The main finding is that including the greatest number of schools and publishing the results of the school's tests contributed to the proper operation of a voucher program. The factors which get in the way of the success of the voucher system are the existence of barriers to entry, unequal financing of public and private schools as well as a low rate of participation of private schools. Böhlmark and Lindhal (2008) evaluated the effects of free choice and competition on the results of private and public 
schools in Sweden. They defined competition as the number of students in a neighborhood who are enrolled in private schools. They found that an increase in participation of private schools improved the results of public schools in the short term.

Gibbons et al. (2008) evaluated if the greater availability of schools and competition between primary schools in England improved academic results. They proxied competition by the Herfindhal index in each zip code area. Initially, they did not find any significant relationship between choice, competition and academic performance, which they attributed to the endogenous relationship between breadth of choice and competition. Then they controlled for endogeneity, using as an instrument the maximum distance travelled by the student, defined by reveled preferences in different transport modes. They found that in the whole sample, competition had a small impact on performance. However, when the population is restricted to the population of Voluntary Aided schools (schools with more administrative freedom), the results show a positive and significant impact on academic performance.

Regarding the Chilean case, Carnoy (1997) suggests that the competition model induced by extensive vouchers has not been effective, as reflected in the high segmentation in schools. McEwan and Carnoy (2000) using cross-sectional data analyzed the impact of competition on the academic performance of fourth graders from 1988 to 1996 . Competition was proxied by the percentage of enrollment in subsidized schools in each neighborhood. The results showed that competition had a negative impact on public schools, and that the effect is greater in neighborhoods with a higher participation of private subsidized schools. The authors contend that this relationship is caused by the migration of the best students to subsidized private schools.

Gallego (2002) develops a model to estimate the effect of competition in municipal and subsidized private schools using SIMCE results and crosssectional data from 1994 to 1997 . He proxied competition as the percentage of private enrollment per municipality, and concluded that competition improved school results in the case of private subsidized schools. He finds a positive correlation between competition and performance, particularly in subsidized private schools, and interprets this as being a consequence of the existence of stronger incentives for a rapid response to potential competition. Hsieh and Urquiola (2003) contend those findings arguing that, after the reform, the private subsidized schools' better showing was primarily due to the fact that they had selected out the best students. They studied the effects of competition on academic performance in math and language in 150 municipalities from 1982 to 1996, defining competition as the participation of private schools in each municipality. They found that when competition increased, the SIMCE results of the public schools fell, but the years of schooling increased.

Auguste and Valenzuela (2004) evaluated the impact of competition on academic results using SIMCE scores for the year 2000. They explicitly assumed that municipalities represent independent markets. The competition proxy is, once again, enrollment in subsidized schools by municipality. They found that higher competition has a positive but small effect on the SIMCE, though an increased inequality of the results and that the segmentation observed within municipalities negatively impacted public schools. 
Chumacero and Paredes (2012b) show the role of information on competition, and Gallegos et al. (2016) develop a model with switching costs. In both cases, they conclude that those costs limit, but not eliminate, competition.

\section{Methodology}

\subsection{Incomplete Analogy between Industrial Organization and Education}

There is wide agreement that firm's return is negatively correlated with different proxies of competition, particularly, market concentration indicators. Whilst the interpretation that associates competition with concentration received important criticism, such as Demsetz (1973), who suggests that the relationship between concentration and return is spurious when size is not controlled for, the Structure-Conduct-Performance paradigm that supports it has had large impact and tends to be specifically applied by antitrust organizations in different countries (Brozen, 1971; Weiss, 1974; Gilbert, 1984). In fact, that is the paradigm implicit in most research analyzing school competition and academic performance. A basic industrial organization model to determine the effect that competition has on return is:

$$
\text { Return }_{i, j}=\alpha+\beta \text { Competition }_{i, j}+\delta^{\prime} X_{i, j}+u_{i, j}
$$

where the return of firm $i$ in the industry $j$ is measured as the ratio of profits and company assets, competition is empirically associated with the industry concentration, $X$ summarizes other controls, and " $u$ " is an error term not related to the competition variable. Equation (1) is typically estimated with cross-sectional data taking advantage of the variance in competition between industries at a given moment of time. The source of that variance is given, for instance, by different barriers to entry.

In the case of education, we are interested in the effect on academic performance and not in financial return. This is however a small technicality, since a competitive process results in dropping prices to attract customers, schools would compete to attract students by providing valuable services, including academic performance. Thus, the analogy between the variables of financial return and educational performance is clear: to maximize return, each school should promote quality, increasing their costs, and reducing return. The competitive pressure will increase costs and academic performance. In short, it is plausible that financial return is negatively related to educational performance and therefore equation (1) can be estimated by replacing return with academic performance (obviously the expected sign for $\beta$ should be positive).

However, there are two main problems to estimate (1) for the case of education in Chile. First, that the competition variable is unclear. School concentration indexes in given areas are meaningless when parents move between areas, as reported in Chumacero et al. (2011). Second, no variance in return among areas should be expected once entry was completed with the reform. Prior to the reform the number of schools was institutionally determined at the Ministry level, and whilst competition among schools was inexistent, the excesses of demand 
for each school varied basically depending on the population around schools. With the reform, the restrictions for the entry of new schools were lifted. This propelled the creation of new schools with no regional or local patterns other than to serve the excesses of demand.

With the reform, schools had to do new things to attract and keep their students. Some schools were more prepared to do so, some had market niches because of their location, or quality. In general thought, it is likely that after the reform the entry of new schools increased competitive pressures and these pressured varied among schools. Thus, we test the basic hypothesis that competition increases learning considering two periods (prior and post entry) for those incumbent schools. Considering two periods, (1) can be empirically expressed as:

$$
\Delta \operatorname{Perf}_{i, t}=\alpha_{0}+\beta_{1} \Delta \operatorname{Comp}_{i, t}+\beta_{2}\left(\Delta \operatorname{Comp}^{*} S T\right)_{i, t}+\beta_{3} \operatorname{Perf}_{i, 0}+\beta_{4} \Delta \operatorname{Control}_{i, t}+\varepsilon_{i, t}
$$

where the dependent variable is the change in the performance in incumbent school $i$ in the period $t ; \Delta \operatorname{Comp}_{i, t}$ is the change in the competitive pressures faced by school $i$ in the period $t, \operatorname{Perf}_{i, 0}$ is the initial SIMCE score of school $i$, and ST is the school type; so $\Delta \operatorname{Comp}^{*} \mathrm{ST}$ is an interactive variable that captures the effect of competition for the different types of schools. ${ }^{4}$ Equation (2) also considers controls for the change in socio demographic characteristics $\left(\Delta\right.$ Control $\left._{i, t}\right)$. We also consider as an instrument of the change in competition, the enrollment in the base year.

\subsection{Market Scope and Competition}

One of the critical aspects to get a good competition proxy is the definition of the market. In general, the literature uses an empirical approach to define it. Over a given threshold for cross elasticities among two goods, a market definition should include both as part of the same market. In the case of education, two schools will be part of the same market if the entry of a new school which charges a fee slightly smaller than the incumbent, significantly affects parents' choice.

The difficulty to define market in education lies in that relevant school characteristics are many. It is in general wrong to define market and the competitive pressures based only in one characteristic, like for instance, distance. Substitution depends on all the factors parents consider relevant to choose them including infrastructure, academic performance, distance, tuition costs, and on the weights they give to each one.

To define the factors parents consider and the weight given to each of them, we follow the school choice model suggested by Chumacero et al. (2011). They index $\mathrm{i}=1, \ldots, \mathrm{I}$ the students in the sample and $\mathrm{j}=1, \ldots, \mathrm{J}$ the possible school choices. Denote by $\mathrm{x}_{\mathrm{i}}$ the vector of characteristics of the student and its household that do not depend on the school, by $y_{i}$ the vector of characteristics of the school that do not depend on the student, and by $z_{i, j}$ the vector of attributes of the school that are specific to each student. Then define $u_{i, j}$ as the (indirect) utility of child $\mathrm{i}$ attending school $\mathrm{j}$, so that:

4 Following Barro and Sala-i-Martin (1992), we considered the SIMCE in the base year as a way to test convergence of results between schools over time. 


$$
u_{i, j}=u\left(x_{i}, y_{j}, z_{i, j}\right)+\varepsilon_{i, j}
$$

where $u($.$) corresponds to a systematic component and \varepsilon_{\mathrm{i}, \mathrm{j}}$ is a (random) nonsystematic component. Given (3), agent i chooses school h if $u_{i, h} \geq u_{i, j} \forall \forall_{j} \neq h$.

Let $d_{i, j}$ denote the distance between household $i$ and school $j$; $d_{n, i}$ the distance between household $i$ and the nearest school; $u_{n, i}$ the value of the utility function in (3) associated with choosing that school, and $u_{m, i}$ the value of the utility function associated to the choice of the school that maximizes (3), $\mathrm{u}_{\mathrm{m}, \mathrm{i}}$ and $\mathrm{u}_{\mathrm{n}, \mathrm{i}}$ will coincide.

Finally, define

$$
\mathrm{v}_{\mathrm{i}}=\left\{\begin{array}{lll}
1 & \text { if } & \mathrm{u}_{\mathrm{m}, \mathrm{i}}=\mathrm{u}_{\mathrm{n}, \mathrm{i}} \\
0 & \text { if } & \mathrm{u}_{\mathrm{m}, \mathrm{i}}>\mathrm{u}_{\mathrm{n}, \mathrm{i}}
\end{array}\right.
$$

where, $v_{i}$ is the (observed) variable that takes the value of 1 when the student attends the school nearest to the household and 0 otherwise.

As mentioned by Chumacero et al. (2011), evaluating (4) instead of (3) is convenient as now we can focus on modeling the determinants of choosing the nearest school using binary response models. Thus, the empirical model to be estimated is:

$$
\operatorname{Pr}\left(\mathrm{v}_{\mathrm{i}}=1 \mid \mathrm{w}_{\mathrm{i}}\right)=\mathrm{F}\left(\beta^{\prime} \mathrm{w}_{\mathrm{i}}\right)
$$

where $\mathrm{F}$ is a distribution function (say the standard normal), $\mathrm{w}_{\mathrm{i}}$ is a vector of determinants, and $\beta$ a vector of parameters to the estimated. ${ }^{5}$ The parameters associated to each of the characteristics parents consider in choosing a school, define the expected utility associated to each choice.

For each student in an incumbent school, we compare the indirect utility associated with that choice and the indirect utility she would have had if a new school had been available. We then define a dichotomous variable $S_{i}=1$ if $U_{i j}^{\text {chosen }} \leq U_{i j}^{\text {new }}, 0$ otherwise. Using $\mathrm{S}_{\mathrm{i}}$ for each student in the incumbent school $\mathrm{k}$, the metric for the increased competitive pressure for each incumbent school is the proportion of the students in an incumbent school that had been better off in a different school had it been available (5).

$$
C_{k}=\sum S_{i} / n
$$

5 As considered in Ferreyra (2007), the choice of school and of residence may be jointly determined. Whilst we have no data to control for the choice of residence, this may not be a prevalent problem in Chile because the vast majority of beneficiaries of the voucher program are from middle income and low income households. They tend to use publicly financed housing programs in which the location of the household is "exogenous" to them. 


\subsection{The Data}

We combine 3 data sets to get our results. The Chilean National Socioeconomic Survey (CASEN) used by Chumacero et al. (2011) does not allow to estimate the competition pressure variable for each incumbent school. In turn, the SIMCE database details the academic performance for each student and school, monthly tuition and the socio-demographic characteristics of the parents of each student, such as gender, family income, education of the father and mother, but does not have information on the home address, needed to compute distance to school. To get distance, we used the College Entrance Exam (PSU) 2009 database provided by The Department of Educational Evaluation, Measurement and Registration of the Universidad de Chile (DEMRE), which includes the student's address when he/she took the test at the end of 12 th grade. This database was combined with the SIMCE tests, which had information regarding the school, the students and their families. We assumed that the student lived in the same location in 2004 , as he/she lived in 2009, so we could have a proxy for the distance between home and school in $2004 .^{6}$

\subsection{Results}

Table 2 shows the results of a Probit estimation for the school choice model, that is, the parameters associated with the different attributes which are valued by families when selecting their school. The results are consistent with economic theory and empirical evidence obtained in Chumacero et al. (2011) in terms that families marginally prefer a closer school in the case of female students, but that probability declines with increased family income and increased level of education of the mother. When there are more schools which are close to the family home, the probability of choosing the nearest school declines. As would be expected, families are more likely to choose the nearest school when its quality is greater or it is closer. Thus, a trade-off between quality, distance travelled by students and the tuition paid is obtained. From the parameters of Table 2, we computed the $\mathrm{Ck}$ variable as suggested above.

The estimation of model (2) differentiated the grade when the SIMCE test was taken. This is necessary due the uneven entry pattern of new schools and the different decisions which are made by parents depending on the age of the child. ${ }^{7}$ The estimation used 2 SLS, to face a possible endogeneity regarding new school location, is presented in Table 3.

The results consistently show that greater competitive pressure significantly increase the performance of private pay schools and private subsidized schools for the $4^{\text {th }}$ and $8^{\text {th }}$ grades, and they show no significant effect for the $10^{\text {th }}$ grade. The results suggest the effect is also positive for public schools, but significantly smaller (join significance test for the coefficients). Finally, the results show a convergence path over time, shown by a negative impact of the initial SIMCE

$6 \quad$ Whilst some families may move over the years, we don't expect a correlation between the new distance and any independent variable, so our estimates will still be unbiased.

7 As an example in 2008, there were 8,829 schools teaching 4th and 8th grade, and 3,675 schools teaching high school. 





TABLE 3

EFFECT OF COMPETITIVE PRESSURES ON ACADEMIC PERFORMANCE (2SLS)

\begin{tabular}{|c|c|c|c|}
\hline \multirow{2}{*}{ Variables } & $10^{\text {th }}$ grade & $8^{\text {th }}$ grade & $4^{\text {th }}$ grade \\
\hline & Coefficient & Coefficient & Coefficient \\
\hline Constant & $\begin{array}{l}-72.7229^{*} \\
(36.3945)\end{array}$ & $\begin{array}{c}-118.7656^{* *} \\
(18.7403)\end{array}$ & $\begin{array}{c}-162.5068 * * \\
(9.2809)\end{array}$ \\
\hline Change in competitive pressure & 0.7502 & $2.5540 * *$ & $1.0459 * *$ \\
\hline (range $0-100)$ & $(0.4448)$ & $(0.2392)$ & $(0.0743)$ \\
\hline Change in competitive pressure $*$ & -0.0269 & $-0.7825^{* *}$ & -0.6605 \\
\hline School Type (Municipal=1) & $(0.0229)$ & $(0.0686)$ & $(0.0468)$ \\
\hline Initial SIMCE score of school & $\begin{array}{c}0.0301 * \\
(0.0258)\end{array}$ & $\begin{array}{l}-0.2304 * * \\
(0.0264)\end{array}$ & $\begin{array}{l}-0.8491 * * \\
(0.0478)\end{array}$ \\
\hline Income variation & $\begin{array}{r}0.0005 \\
(0.0078)\end{array}$ & $\begin{array}{l}0.0369 * * \\
(0.0055)\end{array}$ & $\begin{array}{l}-0.0028 \\
(0.0018)\end{array}$ \\
\hline Tuition variation & $\begin{array}{r}0.0532 \\
(0.0673)\end{array}$ & $\begin{array}{l}-0.0023 \\
(0.0587)\end{array}$ & $\begin{array}{l}0.5520^{* *} \\
(0.0616)\end{array}$ \\
\hline Variation of mother's education & $\begin{array}{l}3.1124^{*} \\
(1.4108)\end{array}$ & $\begin{array}{l}2.7053 * * \\
(0.8382)\end{array}$ & $\begin{array}{c}1.8055^{*} \\
(0.8154)\end{array}$ \\
\hline Variation of father's education. & $\begin{array}{r}1.8253 \\
(1.4257)\end{array}$ & $\begin{array}{l}5.0632 * * \\
(0.8521)\end{array}$ & $\begin{array}{r}0.3610 \\
(0.8132)\end{array}$ \\
\hline \multicolumn{4}{|c|}{ Desviaciones estándar entre paréntesis. ${ }^{*} \mathrm{p}<0.05,{ }^{*} \mathrm{p}<0.01$. } \\
\hline Observaciones & 599 & 526 & 554 \\
\hline $\mathrm{F}(7,592)$ & 1.81 & 20.71 & 52.34 \\
\hline Prob $>F$ & 0.0835 & 0 & 0 \\
\hline R- Squared & 0.0209 & 0.2427 & 0.4345 \\
\hline
\end{tabular}

coefficient. More relevant, the size of the effect of the competitive pressure variable is quite high. Thus, for example, let's consider the differentiated impact on $4^{\text {th }}$ year student performance for two otherwise identical schools. School 1 and 2 had an increase in the competitive pressure they face by 5 and 15, respectively. If both schools were private, that would imply a difference in their performance by 10.4 points. In the case both schools were municipal, the differentiated effect would be 3.9 points. Considering that the standard deviation of the SIMCE test is 50, and that the results have been almost unchanged over the last 10 years, these magnitudes are huge.

\section{Conclusions}

The lack of consensus in the area of education regarding the effect of greater competition on learning or performance, contrasts with the results for other industries. Using a methodology that introduces the idea and measures competitive pressures, we found that competitive pressures do improve significantly and in a relevant way the academic performance of 4th and 8th year students. Secondly, we found that the increase in the competitive pressures positively affect all schools, regardless of the type of administration. It is true that in the case of municipal schools the effect is less important, but still there is an effect 
which is positive and relevant. Our findings contend some previous ideas, in the sense that more competition among schools has significant effects on student performance, not only on private schools, but everywhere.

\section{REFERENCES}

Auguste, S. and Valenzuela J. (2004). "Do Students Benefit from School Competition? The Chilean experience". Doctoral Dissertation, University of Michigan.

Bain J. S. (1956). Barriers to New Competition, Harvard University Press.

Barro, R. J. (1999). "Determinants of economic growth: implications of the global evidence for Chile". Cuadernos de economía, 443-478.

Barro, R. J., \& Sala-i-Martin, X. (1992). Convergence. Journal of political Economy, 223-251.

Bayer, P. and McMillan, R. (2005). "Choice and competition in local education markets", (N, w11802), National Bureau of Economic Research.

Borlan, M.V. and Howsen, R.M. (1992). "Student Academic Achievement and the Degree of Market Concentration in Education". Economics of Education Review, 11:1-39.

Böhlmark, A. and Lindahl, M. (2008). "Does School Privatization Improve Educational Achievement?, Evidence from Sweden's Voucher Reform.

Braun-Munzinger, C. (2005). "Education Vouchers: An International Comparison". Centre for Civil Society.

Brozen, Y. (1971). "Bain's concentration and Rates of Return Revisited”. Journal of Law and Economics, 14:351-369.

Brunner, J. (2005). "Experiencia Internacional y Desafíos Nacionales de Gestión Escolar". Manuscript, Fundación Chile.

Castañeda, T. (1991). "Para combatir la pobreza", Centros de Estudios Públicos, (CEP).

Carnoy, M. (1997). "Is privatization through education vouchers really the answer? A comment on West". The World Bank Research Observer, 12(1), 105-116.

Chubb, J.E. (2001). "The Private Can Be Public", Education Next Spring.

Chumacero, R., Gómez, D. and Paredes, R. (2011). "I would walk 500 miles (if it paid): Vouchers and school choice in Chile". Economics of Education Review, 30(5), 1103-1114.

Chumacero, R. and R. Paredes (2012a). "Vouchers, Choice, and Public Policy: An Overview”. Estudios de Economía, 39(2), 115-122.

Chumacero, R., R. Paredes (2012b). "School Choice and Information". Estudios de Economía, 39(2), 143-157.

Cox, C. (2003). "Las políticas educacionales de Chile en las últimas dos décadas del siglo XX”, Políticas educacionales en el cambio de siglo. La reforma del sistema escolar en Chile, 19-113.

Cox, C. and Lemaitre, M. J. (1999). "Market and state principles of reform in Chilean education: policies and results", Recent policy lessons and emerging challenges, 149-188.

Couch, J. F., Williams, A. L. and Shughart, II. (1993). "Private School Enrolment and Public School Performance”. Public Choice, 76:301-312. 
Demsetz, H. (1973). "Industry Structure, Market Rivalry, and Public Policy". Journal of Law and Economics, 16(1), 1-9.

Epple, D. and Romano, R. (1998). "Competition Between Private and Public Schools, Vouchers, and Peer-Group Effects”. American Economic Review, 88 (1), 33-62.

Ferreyra, M. (2007). "Estimating the Effects of Private School Vouchers in Multidistrict Economies", American Economic Review, 97(3), 789-817.

Friedman, M. (1962). "The Role of Government in Education", in Capitalism and Freedom, Chapter VI, Chicago University Press.

Gallego, F. (2002). "Competencia y Resultados Educativos: Teoría y Evidencia para Chile". Cuadernos de Economía, 39 (118): 309-352.

Gallegos, J., Chumacero, R. and Paredes, R. (2016). "School Choice and Switching Costs", El Trimestre Economico, forthcoming.

García, C. and Paredes R. (2010). "Reducing the Educational Gap: Good Results in Vulnerable Groups", Journal of Development Studies, Vol. 46, № 3 , pp. 535-555.

Gibbons, S., Machin, S., and Silva, O. (2008). "Choice, competition, and pupil achievement", Journal of the European Economic Association, 6(4), 912-947.

Gilbert, R.A. (1984). "Bank Market Structure and Competition: A Survey". Journal of Money, Credit and Banking, 16:617-645.

Hanushek, E.A. (2003). "The failure of input-based schooling policies". Economic Journal, 113(485), F64-98.

Heyneman, S. (1990). "Inequality in Educational Quality: An International Perspective". in D. Verstegen, and J. Ward (Eds.), Spheres of justice in education 1990 American Education Finance Association Yearbook (pp. 103-128). New York: Harper-Collins publishers.

Heyneman, S. (2004). "International education quality". Economics of Education Review, 23(4), 441-452.

Hoxby C. (1994). "Do Private Schools Provide Competition for Public Schools?”. Working Paper, 4978, NBER.

Hoxby C. (2000). "Does Competition Among Public Schools Benefit Students and Taxpayers?". American Economic Review, 90 (5), 1209-1238.

Hoxby C. (2001). "How school choice affects the achievement of public school students", Hill, P. (ed.), Choice with Equity, 150.

Hsieh, C. and Urquiola, M. (2003). "When Schools Compete, How Do They Compete? An Assessment of Chile's Nationwide School Voucher Program”. The American Economic Review, 95, 4; 1310-1326.

Keppler J. (2008). "Barriers to Entry: Abolishing the Barriers to Understanding". Working Paper, LEDa, Université Paris-Dauphine.

Ladd, H. and Fiske, E. (2001). "Does Competition Generate Better Schools? Evidence from New Zealand”. Sanford Institute, Duke University, Working Paper.

Levin, H.M. (2002). "A comprehensive framework for evaluating educational vouchers". Educational Evaluation and Policy Analysis, 24, 159-174.

McEwan P. and Carnoy, M. (2000). "The Effectiveness and Efficiency of Private Schools in Chile's Voucher System". Educational Evaluation and Policy Analysis, 22(3), 213-39. 
Mizala, A. and Romaguera, P. (1998). "Desempeño Escolar y Elección de Colegios: La Experiencia Chilena", Centro de Economía Aplicada, Universidad de Chile.

Mizala, A. and Torche, F. (2012). "Bringing the schools back in: the stratification of educational achievement in the Chilean voucher system". International Journal of Educational Development, 32, 132-144.

Paredes, R. and Pinto, J. (2009). “¿El fin de la educación pública en Chile?”. Estudios de Economía, 36(1), 47-66.

Paredes, R., Opazo, M., Volante, P, and Zubizarreta, J. R. (2013). "Shared financing in the public education in Chile". In Policy proposals to Chile, Centro de Políticas Públicas, Universidad Católica, Chile.

Romano R. and Epple, D. (2002). "Educational Vouchers and Cream Skimming”. Working Paper 9345, NBER.

Rosado, A. (2008). "The success of an economic idea: barriers to entry". IABE2008 Stockholm-Proceedings, Vol. IV (1): 276-286.

Sander, W. (1999). "Private Schools and Public School Achievement". The Journal of Human Resources, 697-709.

Tiebout, C. (1956). "A Pure Theory of Local Expenditures". The Journal of Political Economy, 64(5), 416-424.

Tokman, A. (2004). "Educación y Crecimiento en Educación" ["Education and Growth in Education"]. Documento de Trabajo 289, Banco Central de Chile.

Toma, E. F. (1996). "Public Funding and Private Schooling across Countries". Journal of Law and Economics, 121-48.

Valenzuela, J. P., Bellei, C. and de los Ríos, D. (2008). "Evolución de la Segregación Socioeconómica de los Estudiantes Chilenos y su Relación con el Financiamiento Compartido". Informe Final proyecto Fonide. $N^{\circ}$ : FIE_211 de 2006.

Weiss, L. W. (1974). "The Concentrations-Profits relationship and antitrust”, in H.J. Goldschimid, H.M. Mann and J.F. Weston, eds., Industrial Concentration: The new Learning. Boston: Little, Brown, 184-233. 